Article

\title{
Model to Develop Skills in Accounting Students for a 4.0 Industry and 2030 Agenda: From an International Perspective
}

\author{
Jorge Luis García ${ }^{1,2, *}$ and Ignacio de los Ríos ${ }^{1}$ (D) \\ 1 Escuela Técnica Superior de Ingeniería Agronómica, Alimentaria y de Biosistemas, \\ Universidad Politécnica de Madrid, 28040 Madrid, Spain; ignacio.delosrios@upm.es \\ 2 Carrera de Contabilidad y Auditoría, Universidad Politécnica Salesiana, 010102 Cuenca, Ecuador \\ * Correspondence: jorge.garciaba@alumnos.upm.es
}

check for updates

Citation: García, J.L.; de los Ríos, I. Model to Develop Skills in Accounting Students for a 4.0 Industry and 2030 Agenda: From an International Perspective.

Sustainability 2021, 13, 9699. https:// doi.org/10.3390/su13179699

Academic Editor: Yuzhuo Cai

Received: 12 July 2021

Accepted: 20 August 2021

Published: 30 August 2021

Publisher's Note: MDPI stays neutral with regard to jurisdictional claims in published maps and institutional affiliations.

Copyright: (c) 2021 by the authors. Licensee MDPI, Basel, Switzerland. This article is an open access article distributed under the terms and conditions of the Creative Commons Attribution (CC BY) license (https:// creativecommons.org/licenses/by/ $4.0 /)$.

\begin{abstract}
Since countries around the world have adopted the 2030 Agenda for Sustainable Development, and the concept of Industry 4.0 was externalized at the World Economic Forum in 2016, many investigations have concluded that industries are advancing rapidly through emerging technology projects in a number of fields, enabling them to become more sustainable without neglecting clean and environmentally sound industrial processes. However, this research shows that new accounting graduates lack the key professional competencies required to perform professionally under sustainable accounting standards. Professors and experts agree that traditional teaching methods should be replaced by others that allow recent graduates to better adapt to this new industrial age of sustainability accounting. In this context, we performed an exhaustive analysis of 17 educational methods, in which Delphi was used to survey 46 experts from 26 universities around the world, along with 320 students. This research presents a hybrid model validated by 23 teachers involved directly in its application. In total, $54.82 \%$ of the graduates who participated in this model obtained higher marks in their final graduation exam than those who did not. Thus, these students showed greater development in their accounting skills, enabling them to face the complexities of their professional area in view of the 2030 agenda and the new industrial era.
\end{abstract}

Keywords: sustainability accounting; higher education institutions; university; 2030 Agenda; Industry 4.0

\section{Introduction}

Accounting has become essential to the disclosure of information and establishment of fiscal transparency, ensuring clarity and reliability [1]. However, at present, the development of highly competitive and developed markets has led to a constant process of innovation, causing unforeseen changes in both social, political and demographic areas [2]. The main challenges an accountant faces are globalization, new technologies, increased competencies, changing government regulations, tax reforms, and Industry 4.0 and the 2030 Agenda [3].

Universities must focus their efforts on educational innovation; it is necessary for traditional learning changes to promote social responsibility in students for a sustainable industry according to the 2030 agenda. This can be achieved by innovating practices in the classroom by making use of technologies, through project-based learning, which differs from traditional passive learning [4].

Accounting must continue to evolve, and accountants must adapt to a new technological era, wherein the use of cloud technology, Big Data, block chain, and artificial intelligence all support Industry 4.0 [5]. Here, machines have greater control in the decision-making aspects of production and maintenance, thus improving the performance, degree of automation, data visibility, and the capacity for decision making [6,7]. This forces accountants to develop new skills to face increasing challenges, in order to avoid being replaced by other professions, such as data scientists and technical experts [8]. 
Technology continues to contribute to the constant growth in economic and financial areas, leading to greater effectiveness and efficiency in processes [9,10]. Similarly, the internet in the 21st century has led to the financial progression of companies, expanding their markets to all parts of the world and exchanging financial information [11], as well as adapting traditional industries to a new digital economy and prompting accountants to master information and communications technology (ICT) and become experts in the relevant rules, regulations, and procedures [12].

The International Auditing and Assurance Standards (IAASB) have also supported the collection of data in electronic formats, with some guidelines on how electronic information should be handled. Similarly, enterprise resource planning (ERP), or business intelligence (BI), has made accounting information available in real time, freeing accountants from routine scheduling tasks by creating new capabilities, such as the analysis and interpretation of data $[13,14]$. These are tools that help accountants to carry out various activities, facilitating better communication with departments and making their work much more efficient and effective. This has changed the role of accountants from transaction processors to company advisors [15].

At the same time, the environment has played an important role in society and, since 1990, certain parties have been seeking to promote sustainable development [16], which refers to the ability to satisfy the present needs without harming future generations by including environmental accounting in the economics, reporting structure and legal requirements [17] of companies, with this integration being considered essential [18]. However, this has presented challenges for accountants, such as in keeping accounting records of the results of environmental actions [19].

Similarly, corporate social responsibility practices encourage positive changes in companies according to each country's legislation. Companies must take its capital, work relations and training into account in order to implement those practices; these practices will enable companies to differ from others in the industrial sector and provide them with a positive perspective that will attract investment [20].

Our current society demands entities that assume socio-environmental responsibilities and that can generate reports on environmental impacts to satisfy stakeholders [21]. For this reason, the Global Compact and Global Reporting Initiative (GRI) guidelines were created to prepare reports on sustainability in a regular and standardized way, aiding compliance with socio-environmental indicators. Thus, accountants must consider their impact on the environment, whether negative or positive, and must address their results in respective financial documents [22,23].

In this sense, higher education institutions (HEIs) play a fundamental role in helping new accounting professionals to integrate themselves into this new technological and sustainable era $[24,25]$, allowing them to innovate and adapt to the conditions and demands of Industry 4.0 and the 2030 Agenda [26]. Similarly, teachers must help students to approach social and environmental problems, since accountants must display an advanced ecological, environmental, civic, and ethical profile [27].

University education should help future accountants to develop skills that allow them to make decisions and form judgments, taking social responsibility, respect for diversity, and the construction of citizenship into account [28]. They must also understand that, regarding accountants' professional training, it is not only important to provide the tools needed to investigate, but they must also create interest in research [29], new technologies, and the practice and execution of environmental regulations, providing them with sufficient capacity to propose initiatives that help solve environmental and social problems [30].

Against this background, this article proposes a model that helps accounting students to acquire and improve their professional skills so as to better adapt to an Industry 4.0 and Agenda 2030 context. The model was provided to accounting students from Universidad Politécnica Salesiana in Cuenca, Ecuador in order to determine its effectiveness. The Delphi method was used to determine the competencies that accounting students should have and the best methods to acquire them. 
The objective of this model is to enrich the debate around the methodology of learning professional competences in the accounting field, serving as a basis for the improvement or development of educational models that adapt to this new industrial era and the 2030 Agenda, so that new accounting graduates can help companies formulate sustainable development goals that will help them to disseminate their operating results beyond financial results. This will enable them to show that they have acquired sustainable practices with internal and external effects, since companies that have sustainable development goals are more attractive [31].

In addition, it will prompt universities not to use just one approach when teaching, but to employ a combination of various teaching tools, such as group work, video conferencing, internships, accounting and financial software, and project-based learning. In this regard, this study aimed to improve the current teaching methods used in accounting undergraduate programs by presenting a model that uses a combination of existing methods, which is much more beneficial than when said methods are used individually. This research began in 2016 and ended in 2019 after an analysis of the students' final grades, which helped to determine the effectiveness of the model in one university.

\section{Literature Review}

The following research stands out from previous studies (Table 1).

Table 1. Most relevant revised documents.

\begin{tabular}{clc}
\hline Date & \multicolumn{1}{c}{ Title } & Authors \\
\hline 2008 & $\begin{array}{l}\text { A Critical Theory and a Postmodern Approach to } \\
\text { Teaching Accounting Theory }\end{array}$ & Kieran James \\
\hline 2008 & $\begin{array}{l}\text { Competency-Based Training in Higher Education: } \\
\text { The Complex Approach }\end{array}$ & Sergio Tobón \\
\hline 2010 & $\begin{array}{l}\text { The Gap Between Expectations and Performance in } \\
\text { Accounting Education: An Exploratory Study }\end{array}$ & $\begin{array}{c}\text { Binh Bui } \\
\text { Brenda Porter }\end{array}$ \\
\hline \multirow{2}{*}{2017} & $\begin{array}{l}\text { The decline of the professionally-qualified } \\
\text { accounting academic: Recruitment into the } \\
\text { accounting academic community }\end{array}$ & $\begin{array}{c}\text { Catriona Paisey } \\
\text { Nicholas J. Paisey }\end{array}$ \\
\hline & $\begin{array}{l}\text { Future of Accounting Profession: Three Major } \\
\text { Changes and Implications for Teaching and Research }\end{array}$ & Muhammad Azizul Islam \\
\hline
\end{tabular}

\section{Educational Methods Applied in Accounting}

This section describes the teaching methods that were analyzed by experts and teachers for application in educational models, mainly considering those that could best be adapted to the development of competencies in accounting students, with a focus on Industry 4.0 and the 2030 Agenda. In addition, the best methods should focus on different aspects of students' learning processes: problem-based learning, cooperative learning, case-based learning, peer learning, and project-based learning, as well as other methods.

Problem-based learning was created in 1960 at the University of McMaster, Canada [32]. This method is frequently used in several areas to develop the professional competencies that are important for a university student's profile; it encourages collaborative learning using real problems. Cooperative learning encourages students to work in groups to complete tasks, solve problems, or develop a project that can take several weeks or months; this maximizes everyone's learning and allows students to analyze, ask questions, solve differences in opinion, and work together [33,34]. Case-based learning (CBL) is an approach that drives students to use their knowledge to present solutions to specific scenarios that feature real-life problems. Although there are many claims that CBL is an effective method, there is little evidence to support this claim [35]. Peer-to-peer learning comes from cognitive psychology. This approach enables students to interact with each other and achieve educational goals; it involves students teaching other students and receiving 
mutual help to reinforce their knowledge. It encourages aspects of self-organization that are mostly absent in traditional pedagogical models of teaching and learning [17].

Critics from professions other than accounting believe that the gap between practice and theory must be reduced [13]. A solution suggested is to incorporate hands-on practical experience into university programs such as solution and case study [35], and for professors to foster students' interest in acquiring new competencies that will be useful for their professional development. This can be achieved using project-based methodologies, as stated by organizations such as UNESCO.

Project-based learning (PBL) requires students to learn elements of the basic curriculum, but here, they must also apply what they know to solve real problems. This directs education toward the students' needs, develops competencies, and relates teaching to the professional field that the students and teachers actively participate in, by developing technical, contextual, and behavioral competencies [36,37]. The PBL method is highly relevant to this study because it allows for the identification and standardization of competencies based on real-world problems and criteria. The aim is to first improve said competencies and establish them in the students' academic-professional context. Many universities have adopted this model because it is useful for the development and assessment of competencies in both students and teachers [38].

The use of collaborative projects can help to develop personal competencies that may be used in professional settings, as this method measures one's ability to make good decisions in the face of difficulties [39]. Internships are one of the most important methods in developing professional accountancy competencies because they force students to work in a company and use their accounting skills. Internships are often unpaid; however, the students gain experience in their field [40]. Research projects help students to improve their professional competencies by conducting research in the field of accounting. In class, students read and discuss articles from accounting journals or other sources to improve their understanding of certain topics; they then brainstorm hypotheses and research questions according to what they have read. This helps students to increase their knowledge, skills, and abilities relating to accounting [8].

Other educational methods are used to develop competencies. For example, the use of software enables students to broaden the application of their competencies in accounting [41]. The use of accounting software has had a great impact, allowing students to effectively manage cases and develop technical skills, so that they can adapt to modern company needs [42]. Another method that has helped to develop professional competencies in students is financial consultancy. This method is used so that students can apply the knowledge that they have learned in the classroom in real companies, thereby developing professional competencies. This includes the analysis of financial ratios and the use of software, peer reviews, and reports [43]. There is also a method called integrated projects, which helps students to improve their competencies and become professionally successful. Here, students transfer their theoretical knowledge to hands-on practice by creating a small company, which allows them to gain experience and solve real problems [16].

Educational methods involving integration, communication, and teamwork are helpful because they enable accounting students to build a stronger approach to their learning. These methods allow students to analyze case studies and gain multiple perspectives before coming to an agreement and identifying areas for future research [3]. Lastly, video conferences or online classes are an appropriate teaching method for accountancy. These replace classes using traditional teaching methods [27]. Online classes allow students to learn at any time and in any place, making their study accessible and flexible [10].

In the 1990s, the European Economic Community stated that universities must guarantee students' full development so that they can contribute to the competitiveness of companies. The university is the link between the professional sphere and society; therefore, it is necessary to work on a flexible curriculum that develops the competencies demanded by each academic field. At present, Ecuadorian universities are seeking to change their academic programs to make them more dynamic and produce efficient professionals [1]. 
In this regard, PBL is one of the best methods for evaluating students' knowledge and professional competencies, as working on projects requires students to use theory and develop their knowledge via recent experience [44].

\section{Methodology}

This study involves an analysis of the existing research on accountant competencies and the efforts of universities to reduce the gap between the acquisition of knowledge and the incorporation of that knowledge into hands-on practice in companies involved in this new industrial era. Field research was also carried out to collect information and develop recommendations for how higher education could help improve accounting students competencies. Several methods were analyzed throughout this research to determine the most effective methods for student education, as well as the relationships between them. This enabled us to present a model to guide the teaching-learning process at universities. The model corresponded to the complexity of each year of study, the pace at which students developed knowledge, and the appropriate use of each method in each year of study. To conclude this research, we conducted an experimental trial, wherein the model was applied to undergraduate accounting students at Universidad Politécnica Salesiana's branch campus in Cuenca, Ecuador. Below, in Table 2, a summary of the research participants is presented.

Table 2. Process of collecting information.

\begin{tabular}{|c|c|c|c|}
\hline \multicolumn{4}{|c|}{ Timeline of the Process to Collect Information to Validate the Viability of the Model } \\
\hline Tools used & \multirow{2}{*}{ Delphi Method } & \multirow{2}{*}{$\begin{array}{l}\text { Panel with } \\
\text { professors }\end{array}$} & \multirow{2}{*}{ Surveys to Students } \\
\hline Description & & & \\
\hline Objective & $\begin{array}{l}\text { To determine the main } \\
\text { competencies of an accountant and } \\
\text { the educational methods used to } \\
\text { create them, so they can later be } \\
\text { applied in university classrooms }\end{array}$ & $\begin{array}{l}\text { To evaluate the suitability of the } \\
\text { educational methods proposed in the } \\
\text { hybrid model of methods to be } \\
\text { applied in classrooms and develop } \\
\text { competencies in students. }\end{array}$ & $\begin{array}{l}\text { To determine the year in which } \\
\text { each educational method should } \\
\text { be applied and the relationship of } \\
\text { each method with the different } \\
\text { competencies of an accountant. }\end{array}$ \\
\hline Participants & Accounting experts & $\begin{array}{l}\text { Professors at Universidad Politécnica } \\
\text { Salesiana's branch campus in Cuenca }\end{array}$ & $\begin{array}{c}\text { Students at Universidad } \\
\text { Politécnica Salesiana's branch } \\
\text { campus in Cuenca }\end{array}$ \\
\hline $\begin{array}{l}\text { Number of } \\
\text { participants }\end{array}$ & 46 & 23 & 320 \\
\hline
\end{tabular}

\subsection{Objectives}

The study objective is to analyze the use of different educational methods and arrange them into a new model of higher education that will enable the development of competitive professional competencies, so that accounting and auditing graduates have better job opportunities in the new industrial era.

\subsection{The Aim of the Research Is to Answer the Following Questions}

Can new competencies be developed in accounting students so they can adapt to the goals of the 2030 agenda and be more competitive in this new industrial era?

Is it possible to develop a new model of educational methods in higher education to develop skills in accounting students for a 4.0 Industry and the 2030 Agenda?

\subsection{Hypothesis Development}

The development of a hybrid model of interrelated educational methods, applied progressively throughout the university career, allows for accounting and auditing students to develop competencies that help them develop their professional profile according to the needs of the companies of the new industrial era, which also relate to the context of the 2030 agenda. 


\subsection{Competencies Suggested by the International Federation of Accountants (IFAC)}

In the present research, we considered the five professional competencies suggested by the IFAC [45]:

1. Intellectual;

2. Technical and functional-concerning complex matters related to accounting;

3. Organizational and business management-demanded by the new global context;

4. Interpersonal and communication-essential in organizations;

5. Personal-related to the behavior of each individual.

These five competencies were subdivided to obtain a total of 34 competencies, as shown in Table 3. Each classification refers to a different dimension of the individual's personality, ranging from personal aspects to professional ones. These 34 competencies were analyzed and classified according to their level of importance during the first phase of the Delphi method. This level of importance refers to a rating based on a Likert Scale.

Table 3. Competencies to be analyzed.

\begin{tabular}{|c|c|}
\hline IFAC Competencies & 34 Competencies \\
\hline Intellectual & $\begin{array}{ll}\text { - } & \text { Knowledge } \\
\text { - } & \text { Understanding } \\
\text { - } & \text { Application } \\
\text { - } & \text { Analysis } \\
\text { - } & \text { Synthesis } \\
\text { - } & \text { Locating } \\
\text { - } & \text { Obtaining } \\
\text { - } & \text { Organizing } \\
\text { - } & \text { Identify and solve unstructured problems }\end{array}$ \\
\hline Technical and functional & $\begin{array}{l}\text { - } \\
\text { - } \\
\text { - } \\
\text { - } \\
\text { - } \\
\text { - } \\
\text { Recisioneasurementematical applications, statistics, and } \\
\text { Compliance with legal and regulatory } \\
\text { requirements }\end{array}$ \\
\hline Organizational and management & $\begin{array}{ll}\text { - } & \text { Strategic planning } \\
\text { - } & \text { Project management } \\
\text { - } & \text { Ability to organize and delegate } \\
\text { - } & \text { Motivating and developing human resources } \\
\text { - } & \text { Leadership } \\
\text { - } & \text { Professional judgement } \\
\end{array}$ \\
\hline Interpersonal and communication & $\begin{array}{ll}\text { - } & \text { Solving group conflicts } \\
\text { - } & \text { Teamwork } \\
\text { - } & \text { Interacting with culturally and intellectually } \\
\text { different people } \\
\text { - } \quad \text { Negotiating acceptable solutions and agreements } \\
\text { in professional situations } \\
\text { - Working effectively in an intercultural } \\
\text { environment } \\
\text { - } \quad \text { Submitting reports } \\
\text { Discussing and defending positions effectively } \\
\text { Listening and reading effectively }\end{array}$ \\
\hline Personal & $\begin{array}{ll}\text { - } & \text { Self-management } \\
\text { - } & \text { Initiative, influence, and self-study } \\
\text { - } & \text { Ability to manage resources } \\
\text { - } & \text { Ability to anticipate and adapt to change } \\
\text { - } & \text { Consideration of values and professional attitude } \\
& \text { to make decisions } \\
\text { - } & \text { Ethics }\end{array}$ \\
\hline
\end{tabular}




\subsection{Participants}

Our field research was based on the working with people (WWP) model, which is appropriate because it meant that the people who were directly involved in the research could actively and openly contribute and participate in the different activities that were planned by the researchers. The working with people methodology was chosen because, for a project seeking to influence the behavior of a group of people, it is important for them to learn the important aspects and areas where they want to improve from their own experience, and the WWP allows for these uncontrolled aspects to be worked with directly [46]. Accounting experts, professors, and students took part in the research.

\subsubsection{Delphi Method}

The Delphi method was used to survey a panel of experts and a panel of professors and students, who were asked to evaluate the methods. This method was selected because it is a flexible tool to collect opinions from a diverse group of experts on a certain topic. It is a way of analyzing the opinions of experts with different perspectives and is widely used in doctoral or master's degree research due to its flexibility [47]. It is designed to gather sufficient information for decision-making. The participants do not know each other, and their responses are anonymous, which helps to obtain reliable results.

A total of $35 \%$ (16) of the experts who took part in the Delphi survey were women, and $65 \%$ (30) were men. They were between 27 and 71 years old. A total of $63 \%$ (29) of the experts had a master's degree and 29\% (13) had a Ph.D. degree or were about to complete one. The experts had broad experience in accounting and auditing, and they had management positions or were professors in university faculties. A total of $50 \%$ (23) of the experts worked only as professors, while the other $50 \%$ (23) worked both as professors and in companies.

The Delphi survey was applied in three languages (English, Spanish, and Portuguese) to 46 experts from 26 universities (Table 4) in Australia, Bolivia, Brazil, Ecuador, El Salvador, Romania, Spain, USA, Mexico, New Zealand, the United Kingdom, and South Africa. This provided a global perspective on the competencies that accounting students must develop at university.

To contact experts, a database of universities was used. The data collection was conducted virtually. An email was sent to 950 teachers from around the world. The 46 experts selected were those who showed a willingness and enthusiasm to develop a model that helps accounting students to develop relevant skills to the new industrial era and the 2030 Agenda.

The process used in this study, according to the Delphi method, was as follows:

1. Prepare a database with information pertaining to accounting experts from each continent to obtain a global perspective based on their experience and the reality of the educational system in their country;

2. Prepare a questionnaire to collect expert opinions on the development of the 34 competencies and have it completed by the experts to obtain primary information according to their professional experience (Appendix A);

3. Manage the information through factor analysis to obtain a synthesis of the results after the first phase;

4. Arrange the second questionnaire, the objective of which is to ask experts about the importance of each of the 17 educational methods, and their relevance to different competencies (Appendix B);

5. Arrange the educational methods chosen by the experts such that they can later be applied to students. 
Table 4. List of universities and number of experts.

\begin{tabular}{ccc}
\hline Number of Experts & University & Country \\
\hline 1 & University of Western Australia & Australia \\
1 & Politehnica University of Bucharest & Romania \\
1 & Escuela Militar de Ingeniería & Bolivia \\
1 & Universidad Mayor de San Andrés & Bolivia \\
1 & Universidad Salesiana de Bolivia & Bolivia \\
2 & Centro Universitario Salesiano de San Pablo & Brazil \\
2 & Pontificia Universidad Católica de San Pablo & Brazil \\
1 & Universidad de Campinas & Brazil \\
1 & Universidad Guarulhos & Brazil \\
1 & Universidad Metodista de Piracicaba & Brazil \\
1 & Universidad Católica de Cuenca & Ecuador \\
4 & Universidad de Cuenca & Ecuador \\
6 & Universidad del Azuay & Ecuador \\
5 & Universidad de El Salvador & El Salvador \\
3 & Universidad Complutense de Madrid & Spain \\
3 & Universidad de Burgos & Spain \\
2 & Universidad de Valladolid & Spain \\
1 & Universidad Politécnica de Madrid & Spain \\
1 & University of California & United States \\
1 & Instituto Politécnico Nacional & Mexico \\
1 & Universidad Chapultepec & Mexico \\
1 & University of Auckland & Mexico \\
1 & University of Manchester & Mexico \\
1 & Universidy of Pretoria & New Zealand \\
1 & Universidad Nacional Autónoma de México & South Africa \\
2 & Autónoma de Nuevo León-México &
\end{tabular}

Source: Own elaboration.

The questionnaires were based on the recommendations provided by Stott and Ramil [48], working at the Centro de Innovación en Tecnología para el Desarrollo Humano at Universidad Politécnica de Madrid:

- Know who your study is aimed at;

- Focus on the information you wish to obtain;

- In the questionnaire, explain how the information will be used;

- Write different types of questions to avoid a repetitive questionnaire;

- Request information that allows you to determine the respondents' profiles;

- Write clear questions that encourage honest answers;

- The questions must be in accordance with each other.

\subsubsection{Panel with the Professors}

To determine the functionality of the methods selected by the experts, a panel was held with a group of 23 professors heavily involved in the accounting undergraduate program at Universidad Politécnica Salesiana's branch campus in Cuenca and this panel was guided by a questionnaire (Appendix C). They were full-time professors, heads of academic areas, and professors in charge of internships and community engagement. The professors on the panel had about 10 years of teaching experience on average. In total, 91\% of them had a master's degree and the remaining $9 \%$ had a doctorate.

The aim of this panel was to address the hypothesis, which stated that the use of new educational methods will help to develop professional competencies in accounting students that are relevant to the new industrial era and the 2030 Agenda. Finally, the professors were asked to evaluate the competencies and methods.

\subsubsection{Participation of the Students}

To support the findings obtained using the Delphi method regarding the experts' opinions on the best methods to develop competencies, as well as the professors' views, ac- 
counting students from the three branch campuses of the Universidad Politécnica Salesiana in Quito, Guayaquil, and Cuenca in Ecuador were asked to respond to a questionnaire (Appendix D). The student population consisted of 1268 students and the sample size was 320 students.

\section{Determining Sample Size}

The formula is used for samples of finite populations [49], and the usual levels of confidence and error are used, which are $95 \%$ and $5 \%$, respectively:

$$
n=\frac{N *\left(v_{c} * e\right)^{2}}{1+\left(e^{2} *(N-1)\right)}
$$

$v_{\mathcal{C}} \rightarrow$ confidence value $=95 \%$

$e \rightarrow$ Marin of error $=5 \%$

$N \rightarrow$ Population size 1268 students

$n \rightarrow$ Sample size

$$
\begin{gathered}
n=\frac{1268 *\left(0.95_{c} * e\right)^{2}}{1+\left(e^{2} *(N-1)\right)}=295 \\
n=\frac{1268 *\left(0.95_{c} * 0.05\right)^{2}}{1+\left(0.05^{2} *(1268-1)\right)}=295
\end{gathered}
$$

$n=295$.

According to the formula, 295 students were obtained, but given the opportunity, 320 surveys were carried out, for which the degree of confidence remains $95 \%$ and the error was reduced to $4.74 \%$.

The students were in different years of study. In total, $29 \%$ were men and $70 \%$ were women, while the remaining 1\% did not specify their gender; $31 \%$ were first-year students, $28 \%$ second-year students, $18 \%$ third-year students, and $24 \%$ were senior students.

The information collected from the students was significant as, when combined with the WWP methodology, it enabled each student to become personally involved with the research and contribute more [50].

Through the questionnaire, the students were asked about the methods to determine in which of them they had participated. Then, this information was used to create a hybrid model of methods based on their needs. To complement the analysis, students were also asked about the year of study in which they thought each method should be applied.

\subsection{Educational Methods Applied at the Universidad Politécnica Salesiana}

We analyzed the 17 educational methods used at the three branch campuses at the Universidad Politécnica Salesiana at the time this research started, during the second phase of proceedings, with the panel of experts. These methods were suggested by professors during the Academic Council meeting of the accounting and auditing undergraduate program before the start of academic period \#51, in 2017, according to the guidelines of the university's statute, whereby Article 5 states that the university must guarantee the students' acquisition of competencies, a statement that was approved by the Ecuadorian Higher Education Council. The 17 methods were:

1. Students teaching accounting subjects in high schools;

2. Working in an accounting and tax advisory office, where students help people in the community and small-scale entrepreneurs;

3. Creating accounting spreadsheets;

4. Making financial statements in real companies;

5. Teaching reinforcement courses on accounting;

6. Learning through video conferencing;

7. Group work in the classroom; 
8. Use of accounting commercial software in the classroom;

9. Professional internships in real companies;

10. Offering advice about entrepreneurship, sustainability accounting, taxation, and basic finance to people in rural communities;

11. Management consulting in real companies;

12. Individual or group tutorials;

13. Business simulation in the classroom;

14. Study of real fraud cases;

15. Meetings with alumni to discuss their experiences;

16. Learning through research and academic articles;

17. Project-based learning (PBL).

Each method was rated from 1 to 5 on a Likert Scale, with 1 being the most important and 5 being the least important. To reduce the methods to those that enhanced student competencies the most, factor analysis was applied.

\section{Results and Discussion}

The results of the quantitative and qualitative analysis of the participation of the experts, professors, and students are presented below.

\subsection{Delphi Method with the Experts}

Regarding the methods applied in universities, we focused on the use of methodologies that encouraged hands-on practice versus traditional theoretical methodologies. This analysis was performed using questionnaires that were answered by experts, professors, and students. Question 11 from the questionnaire asked experts about the use of traditional methods versus modern ones, wherein $89 \%$ agreed that universities must use methods that prioritize the use of hands-on activities to improve the development of competencies.

The experts explicitly pointed out that the use of more practical methods would complement the students' education, allowing them to acquire the skills needed for their professional career, as well as generating self-confidence. They explained that if the universities devised activities or projects connected to real companies, students would acquire direct experience in the professional field. They added that the contextualization of concepts would help students to assimilate knowledge and stop them from being passive learners.

For the second stage of the Delphi method, that of working with the experts, a factorial analysis was used, which allowed for a reduction in the number of educational methods and working in the second stage of the Delphi method only with those that have the greatest interrelation. To carry out this analysis, the SPSS program was used to perform the corresponding tests, such as the chi-square values that present precise information for the validation of the analysis and after these, the results of the factorial analysis were obtained in the same software.

The chi square value seeks to determine the independence of one variable against another. The null hypothesis is that the methods are not related to each other and an alternative hypothesis is that, if they are related, the accepted significance level is 0.05 , as indicated in Table 5. If a significance lower than this value is obtained, the alternative hypothesis is considered valid, determining that the methods are interrelated and that they depend on each other. 
Table 5. KMO and Bartlett test.

\begin{tabular}{|c|c|c|}
\hline \multicolumn{3}{|c|}{ KMO and Bartlett Test } \\
\hline \multicolumn{2}{|c|}{ Medida Kaiser-Meyer-Olkin de adecuación de muestreo } & 0.860 \\
\hline \multirow{3}{*}{ Bartlett's test of sphericity } & Approx. Chi-square & 760,161 \\
\hline & df & 136 \\
\hline & Sig. & 0.000 \\
\hline
\end{tabular}

Source: Own elaboration.

The correlation index used was Spearman, which is generally used in factor analysis. Since this was a weak value, the correlations between the methods were high and it was possible to continue the analysis. The Kaiser-Meyer-Olkin (KMO) and Bartlett tests were performed, guided by the analysis parameters, where $0.7<\mathrm{KMO}$ was considered acceptable, confirming the validity of the analysis (Table 5). The rotated component matrix, shown in Table 6, demonstrates how the variables were related. For the analysis, the extraction method used was analysis of principal components and the rotation method was Varimax with Kaiser normalization

Table 6. Rotated component matrix of educational methods in Delphi.

\begin{tabular}{|c|c|c|c|}
\hline \multicolumn{4}{|l|}{ Rotated Component Matrix } \\
\hline & \multicolumn{3}{|c|}{ Component } \\
\hline & 1 & 2 & 3 \\
\hline Management consultation in real companies & 0.871 & & \\
\hline Internships in real companies & 0.815 & & \\
\hline Completion of financial statements in real companies & 0.794 & & \\
\hline $\begin{array}{l}\text { Office run by students for accounting and taxation advice for the } \\
\text { community and small companies }\end{array}$ & 0.773 & & \\
\hline Study of real fraud cases & 0.770 & & \\
\hline $\begin{array}{l}\text { Consultancy on entrepreneurship, accounting, taxation, and basic } \\
\text { finance in rural communities }\end{array}$ & 0.770 & & \\
\hline Accounting software in the classroom & 0.753 & & \\
\hline Transfer of experiences with former students & 0.631 & 0.549 & \\
\hline Project-based learning & 0.605 & 0.578 & \\
\hline Completion of accounting processes in spreadsheets (Excel) & 0.514 & & \\
\hline Group work in the classroom & & 0.875 & \\
\hline Learning through video conferences & & 0.855 & \\
\hline One-to-one or group tutorials & & 0.752 & \\
\hline Business simulation in the classroom & 0.577 & 0.740 & \\
\hline Reinforcement courses & & 0.735 & \\
\hline Learning through research and academic articles & 0.525 & 0.677 & \\
\hline Accounting classes in high schools taught by university students & & & 0.938 \\
\hline a. Rotation converged in 5 iterations & & & \\
\hline
\end{tabular}

Source: Own elaboration.

According to Martin et al., the methods are grouped according to the component in which they have the highest score, which is why they are grouped in this way [49].

Since the coefficients of this matrix were organized by size, each component was correlated to one variable of each of the other components, resulting in three components or groups of methods (variables). At this stage of analysis, the educational models were 
divided into two groups. The experts who took part in the Delphi method were consulted to determine the most relevant methods in each group, and then asked to come to an agreement on the most important ones, which would then be used to develop the hybrid model.

The third component contained only one variable with no relation to any other; therefore, this method (accounting classes in high schools taught by university students) was not considered. Following these results, only 16 methods were considered for the rest of the investigation. The two groups of methods that were used in the hybrid model are presented in Table 7, according to their importance to the development of competencies.

Table 7. Classification of educational methods-Delphi results.

\begin{tabular}{|c|c|c|c|}
\hline & Component 1 & & Component 2 \\
\hline 1. & $\begin{array}{l}\text { Management consulting in real } \\
\text { companies }\end{array}$ & 1. & Group work in the classroom \\
\hline 2. & Internships in real companies & 2. & Learning through video conferences \\
\hline 3. & $\begin{array}{l}\text { Completion of financial statements in } \\
\text { real companies }\end{array}$ & 3. & One-to-one or group tutorials \\
\hline 4. & $\begin{array}{l}\text { Office run by students for accounting } \\
\text { and taxation advice for the community } \\
\text { and small companies }\end{array}$ & 4. & Business simulation in the classroom \\
\hline 5. & Study of real fraud cases & 5. & Reinforcement courses \\
\hline 6. & $\begin{array}{l}\text { Consultancy of entrepreneurship, } \\
\text { accounting, taxation, and basic finance } \\
\text { in rural communities }\end{array}$ & 6. & $\begin{array}{l}\text { Learning through research and } \\
\text { academic articles }\end{array}$ \\
\hline 7. & Accounting software in the classroom & & \\
\hline 8. & $\begin{array}{l}\text { Transfer of experiences with former } \\
\text { students }\end{array}$ & & \\
\hline 9. & Project-based learning & & \\
\hline 10. & $\begin{array}{l}\text { Completion of accounting processes in } \\
\text { spreadsheets (Excel) }\end{array}$ & & \\
\hline
\end{tabular}

\subsection{Panel with Professors from the Universidad Politécnica Salesiana}

The panel encouraged professors to interact and determine the effects of the 17 methods on the development of student competencies. Regarding the methods applied in universities (question 4), 100\% of professors believed that the use of projects in the classroom is the most effective method for the development of competencies. Therefore, this method should be applied throughout accounting undergraduate programs.

\subsection{Questionnaire Given to Students}

Students' participation also included a Likert Scale rating for the educational method, regarding whether they consider the method to have influenced the development of their professional skills. Table 8 shows the results obtained. 
Table 8. Educational methods graded by students.

\begin{tabular}{|c|c|c|c|c|c|}
\hline Ratings $\rightarrow$ & 1 & 2 & 3 & 4 & 5 \\
\hline \multicolumn{6}{|l|}{ Methods $\downarrow$} \\
\hline Management consulting in real companies & $6 \%$ & $7 \%$ & $14 \%$ & $24 \%$ & $49 \%$ \\
\hline Internships in real companies & $7 \%$ & $4 \%$ & $8 \%$ & $18 \%$ & $63 \%$ \\
\hline Completion of financial statements in real companies & $6 \%$ & $5 \%$ & $10 \%$ & $21 \%$ & $58 \%$ \\
\hline $\begin{array}{l}\text { Office run by students for accounting and taxation advice } \\
\text { for the community and small companies }\end{array}$ & $8 \%$ & $5 \%$ & $12 \%$ & $20 \%$ & $55 \%$ \\
\hline Study of real fraud cases & $8 \%$ & $5 \%$ & $16 \%$ & $23 \%$ & $48 \%$ \\
\hline $\begin{array}{l}\text { Consultancy of entrepreneurship, accounting, taxation, and } \\
\text { basic finance in rural communities }\end{array}$ & $6 \%$ & $6 \%$ & $14 \%$ & $16 \%$ & $58 \%$ \\
\hline Accounting software in the classroom & $5 \%$ & $6 \%$ & $13 \%$ & $21 \%$ & $55 \%$ \\
\hline Transfer of experiences with former students & $8 \%$ & $10 \%$ & $22 \%$ & $26 \%$ & $34 \%$ \\
\hline Project-based learning & $6 \%$ & $5 \%$ & $16 \%$ & $28 \%$ & $45 \%$ \\
\hline Completion of accounting processes in spreadsheets (Excel) & $6 \%$ & $3 \%$ & $8 \%$ & $22 \%$ & $61 \%$ \\
\hline Group work in the classroom & $4 \%$ & $6 \%$ & $14 \%$ & $26 \%$ & $50 \%$ \\
\hline Learning through video conferences & $8 \%$ & $13 \%$ & $18 \%$ & $19 \%$ & $42 \%$ \\
\hline One-to-one or group tutorials & $6 \%$ & $6 \%$ & $14 \%$ & $23 \%$ & $51 \%$ \\
\hline Business simulation in the classroom & $9 \%$ & $5 \%$ & $11 \%$ & $21 \%$ & $54 \%$ \\
\hline Reinforcement courses & $10 \%$ & $6 \%$ & $13 \%$ & $25 \%$ & $46 \%$ \\
\hline Learning through research and academic articles & $6 \%$ & $5 \%$ & $12 \%$ & $24 \%$ & $53 \%$ \\
\hline
\end{tabular}

The results in the evaluation of the methods show that the opinion of the students confirms that the methods are highly effective in developing classroom skills. In total, 100\% of students agreed that their learning would be better if their professors used hands-on practice methods more than theoretical ones. A significant number of students used several methods: $73 \%$ of the students participated in classroom activities, $68 \%$ in the research and study of academic articles, $48 \%$ in business simulations, $65 \%$ in creating accounting spreadsheets, and $64 \%$ in project-based learning. There were 10 methods in which only $11-35 \%$ of the students participated, namely the completion of financial statements of real companies; using accounting software in the classroom; undertaking internships in real companies; the study of fraud cases; the transfer of experiences of former students; learning via video conferences; undertaking courses to strengthen knowledge in accounting; running an accounting and tax advisory office; running management consultation with real companies; offering consultancy on entrepreneurship, accounting, and taxation and basic finance to rural communities.

Both experts and students provided information on when the methods should be implemented. The results are satisfying because they coincide with those of similar studies focusing on the benefits of using hands-on practice methods in the teaching and learning process, such as a study published in Argentina concerning Harvard University's claim that one of the most effective study methods is solving new problems, which supposedly means that new challenges are raised in each situation and the simple repetition of theory is avoided [51].

All the research techniques applied with experts, students and professors showed that the model was effective. 


\section{Creation of a Hybrid Model of Methods Based on the Results Obtained from the Delphi Method and the Questionnaires Applied to Students}

The hybrid model was created based on the results obtained via the Delphi method and students' opinions regarding the different educational methods used in their undergraduate accounting program. Accounting programs generally take four or five years to complete. In Ecuador, where the hybrid model was applied, completing an accounting undergraduate program takes four and a half years, as well as a final graduation project. The hybrid model presents the year of study in which each method should be used; a four-year curriculum was used as the reference.

According to the results derived from the Delphi method, as well as the students' responses and the professors' opinions, project-based learning can be used during the entire undergraduate program in all years of study, but should be used carefully during the first year because students' knowledge is limited. In the third year of study, it is possible to use teaching methods that incorporate knowledge and information from all the subjects being taught that year; this will enable the development of (1) negotiation skills, (2) organization skills, and (3) leadership and motivation, as well as helping with (4) the creation of project objectives, (5) the improvement of students' fulfillment of deadlines and stages when working on projects, and (6) development of an orientation toward working on projects.

The experts agreed that tutoring should be given from the beginning to the end of the undergraduate program (four or five years, depending on the country the university is in).

When using the hybrid model of methods, professors must know that their guidance will be very important during the first year, because of the students' limited level of knowledge. The degree of guidance will progressively decrease as the students move on, and will become almost unnecessary in their senior year, since their knowledge will have reached almost professional levels.

The research carried out by Moncada [14] at the Universidad Técnica Particular de Loja supports the hybrid model presented in this research; it supports the idea that the involvement of students in hands-on practice activities is not only favorable for their education, but also ensures a more accurate evaluation of their academic progress, which allows universities to adjust the design of academic methods according to students' needs.

According to the hybrid model, the methods that should be applied in the different years of study are listed below:

- In the first year, to develop their ability to debate, predict needs, create projects, close contracts, develop financial skills, teamwork skills, and creativity, and become result-oriented, the methods include the use of accounting software, the undertaking of group work in the classroom, the transfer of experiences with former students, engagement in learning through research and academic articles, partaking in business simulations in the classroom, learning through video conferences and reinforcement courses, and the completion of accounting processes in spreadsheets (Excel).

- Second-year students should use accounting software in the classroom and take part in the completion of financial statements in real companies; undertake management consultation in real companies; offer consultancy on entrepreneurship, accounting, taxation, and basic finance to rural communities. This will help them develop business communication skills.

- Third-year students must become more involved with the completion of financial statements in real companies; undertake internships in real companies, the study of real fraud cases, and reinforcement courses; run offices offering sustainability accounting and taxation advice to the community and small companies; undertake management consulting in real companies; offer consultancy on entrepreneurship, accounting, taxation, and basic finance to rural communities to develop various competencies (reliability, human resources management, moving from theory to practice, managing stress and work pressure, identifying risks and opportunities, efficient portfolio management, ethical work practice, knowledge of laws, report preparation, the appreciation of values, and the integration of processes). 
- Fourth-year students must take part in the completion of financial statements in real companies, internships in real companies, the study of real fraud cases, sustainability accounting report generation, video conferences, and learning through research and academic articles related to Industry 4.0 and the 2030 Agenda. These five methods will help develop competencies such as commitment to work and an orientation toward programs.

To put the hybrid model into action, a bidirectional application strategy, as shown in Figure 1, is required to reduce the degree of professorial guidance while increasing students' autonomy until they complete their Final Graduation Project (FGP).

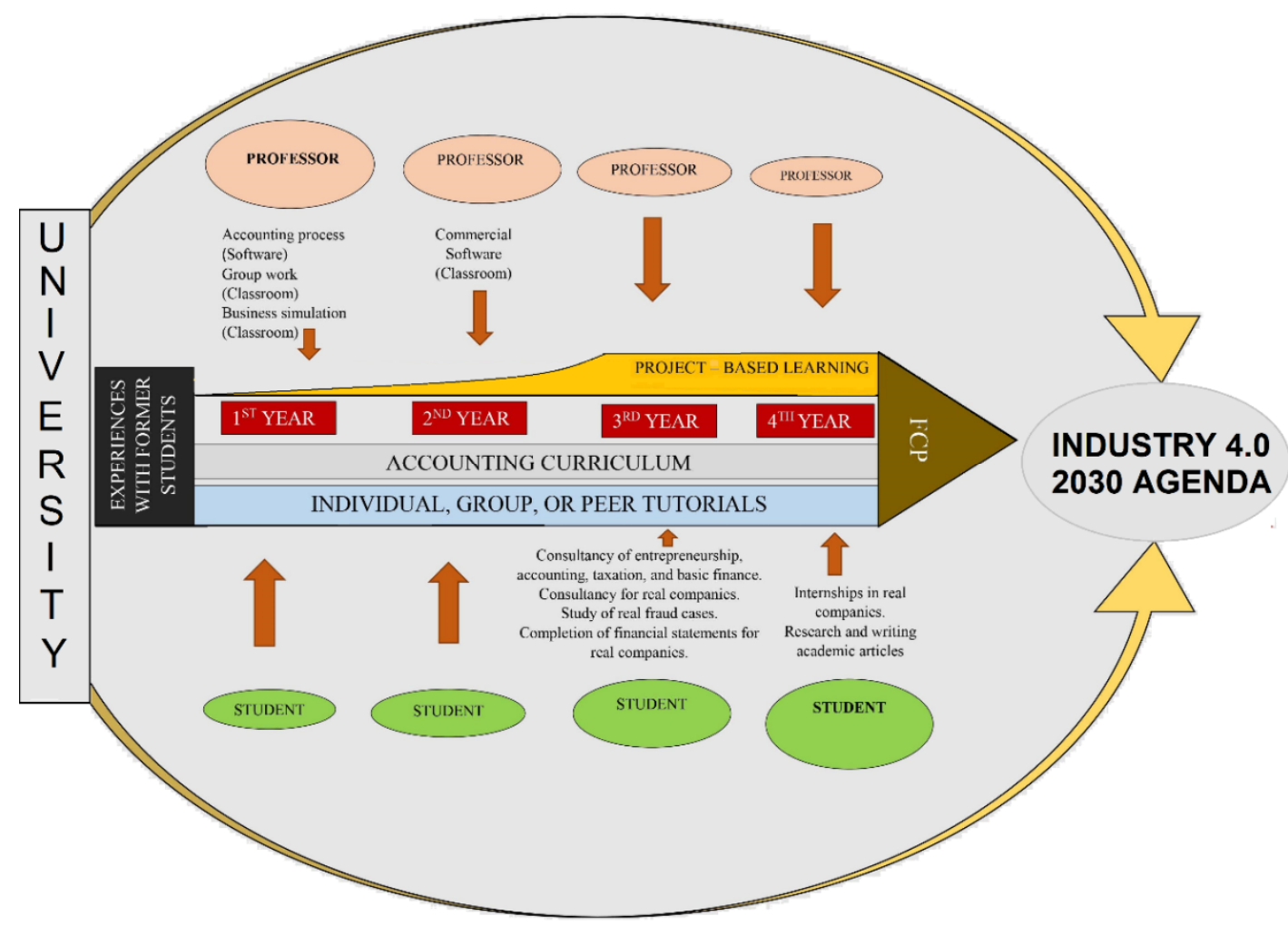

Figure 1. Model to develop skills in accounting students relevant to Industry 4.0 and the 2030 Agenda.

The bidirectional strategy allows for professors and students to contribute to the process of educating professionals, complemented by other quality processes [52].

\section{Application of the Hybrid Model of Educational Methods for the Development of Accounting Student Competencies}

Once the above-mentioned methods were added to the university curriculum, the students were more ready to fulfill their final graduation project and demonstrate their ability to become professional accountants who can meet the current demands of companies. We verified the positive influence of the hybrid model of methods on students' performance at the Universidad Politécnica Salesiana's branch campus in Cuenca by comparing their final exam grades to the grades of students at the university's branch campus in Quito, where a traditional teaching method was used. Students from the university's branch campus in Quito experienced very little to no participation in educational projects; on the other hand, the students at the university's branch campus in Cuenca actively participated in projects throughout their years at the university.

In graded academic assessments, most of the content should concern the practical application of knowledge: $20 \%$ should be aimed at measuring students' memorization, $30 \%$ at measuring students' understanding, and $50 \%$ at measuring their ability to apply knowledge [15]. 
To successfully graduate, students had to obtain at least 70 out of 100 points on their final graduation project. At the university's branch campus in Cuenca, $54.82 \%$ of students presenting a final graduation project (the vast majority of which focused on research related to the 2030 Agenda and Industry 4.0) achieved grades between 91 and 100, while in Quito, only $1.69 \%$ of students who completed a final graduation project achieved grades within that range. We found that $80.07 \%$ of the graduates from the university's campus in Quito achieved grades between 70 and 80, thus demonstrating the positive results of the hybrid model.

\section{Conclusions}

The experts who took part in the Delphi method agreed with other research [4] that stated that universities should consistently apply more hands-on teaching methods to develop specific competencies in accounting students. Therefore, they supported the use of the hybrid model of methods. By applying the model, the accounting students were able to develop the competencies required by the job market [25], thus precluding the need for employers to invest in additional training.

Students and professors agree that, at the university, less than $35 \%$ of students take part in hands-on practice activities, and $89 \%$ of professors agree that traditional teaching methods should be replaced [27]. The results reflect the recommendations of experts, the favorable responses of students, and the better grades achieved in final exams and graduation projects. This model allowed for students to connect with the real world and gain a more up-to-date view of sustainability accounting [53], Industry 4.0, the 2030 Agenda, and the future of accounting [25].

Other studies [54] have shown that higher education must contribute to sustainable development; therefore, the educational methods model presented in this research enables students to develop the professional skills that are needed in the context of the 2030 Agenda.

The hybrid model combines the best educational methods that can be used in accounting undergraduate programs to ensure that graduates are able to contribute to the sustainability of the new 4.0 industry and meet the needs of companies [55].

The research states that the time spent presenting concepts in class should not exceed the time spent presenting practical case studies that simulate real situations that accounting professionals will encounter [3]. The hybrid model of methods is a teaching approach that incorporates the active participation of professors and students into the development of competencies by the undergraduate program.

The model also contributes to the evolution of the educational system by encouraging a union between knowledge and practice [4], and by integrating basic and specific competencies [45]. This study suggests a flexible model, using methods in accordance with the specific context of each academic level throughout the program. This method will also enable students to properly use and disseminate their knowledge when developing competencies. The model opens the door to a debate regarding the learning methodologies used in the development of professional competences in the accounting field, serving as a basis for the improvement or development of educational models that are adapted to this new industrial era and the 2030 Agenda [56].

This study was limited by a certain resistance to change [57], which may have come from professors with a traditional teaching approach who are not willing to modernize their classes and adapt their mindset to the new industrial era and the 2030 Agenda.

The analysis of accountants' competencies relates to other potential future research topics, such as (1) the significance of professional skills acquired at university when overcoming difficulties in accounting jobs in the new industrial era; (2) how to focus on the competencies accountants must have, according to the needs of different industries; (3) the analysis of the role of accountants in Industry 4.0 and the 2030 Agenda.

Author Contributions: Both authors (J.L.G., I.d.1.R.) contributed to conceptualization, formal analysis, methodology, research, resources, software, data retention, preparation of the original written draft and translation. All authors have read and agreed to the published version of the manuscript. 
Funding: This research did not receive external funding.

Institutional Review Board Statement: The study was conducted according to the guidelines of the Declaration of Helsinki.

Informed Consent Statement: Informed consent was obtained from all subjects involved in the study.

Data Availability Statement: All data regarding the results of this research are available.

Acknowledgments: We want to thank the Finance, Audit, Accounting and Taxation Research Group (GIFACT) of the Accounting and Auditing Faculty of Politécnica Salesiana University Cuenca, Ecuador, for allowing us access to the necessary information to carry out this investigation.

Conflicts of Interest: The authors declare not to have a conflict of interest.

\section{Appendix A. Questionnaire for Research on the Development of Competences in Accounting Students}

Presentation:

Please answer the following questions. Thank you.

1. Gender

- Female

- Male

- Other

2. Age

3. Email

4. First and last name

5. Country

6. Indicate your highest degree you have completed

- Bachelor's degree

- Master's Degree

- Advanced Graduate work or Ph.D.

7. What is the name of the University in which you studied?

8. Indicate your economic activity. (You can select more than one option if it is necessary).

- Professor

- Autonomous worker

- Professional in relation of dependence

- Other

9. How many years of professional experience do you have?

10. Have you noticed the lack of any professional competences in graduates of careers related to the accounting area, when they worked with you?

- Yes

- Not

If you have indicated "Yes", indicate which or which ones.

11. Do you think that universities should apply more practical teaching methods in ordert to develop certain competences in accounting students?

- Yes

- Not

Why?

12. Do you think that recently graduated professionals from accounting careers can manage a companies' software without any problems?

- Yes

- Partially

- Not 
Why?

13. Do you consider that the Careers, Schools or Accounting Faculties should increase socio-economic projects, such as taxation, accounting and financial consulting services or education programmes aimed to support the community or the company?

- Yes

- Not

Why?

14. Do you consider that the mentioned consulting projects, and the interaction with real companies throughout the university career, contributes to the development of competences in the students?

- Yes

- Not

Why?

15. Do you consider that the methods of teaching used in accounting schools or faculties in the university are mostly theoretical nowadays?

- Yes

- Partially

- Not

Why?

16. Do you consider that there are competences that can be evidenced only in an accountant?

- Yes

- Not

If you have indicated "Yes", indicate which or which ones.

17. Rate the current educational system of accounting careers in your country; consider "1" very good and " 5 " very bad.

18. Indicate the level of complexity of the technical-business environment in the accounting profession; consider " 1 " the most complex and " 5 " the least complex.

\begin{tabular}{|c|c|c|c|c|c|}
\hline \multirow{2}{*}{ Technical-Business Environment } & \multicolumn{5}{|c|}{ Complexity } \\
\hline & 1 & 2 & 3 & 4 & 5 \\
\hline \multicolumn{6}{|l|}{ Develop objectives } \\
\hline \multicolumn{6}{|l|}{ Identify needs for change when there is uncertainty } \\
\hline \multicolumn{6}{|l|}{ Manage times to achieve goals } \\
\hline \multicolumn{6}{|l|}{ Develop tasks in different degrees of complexity } \\
\hline \multicolumn{6}{|l|}{ Application of different methods to develop the same task } \\
\hline \multicolumn{6}{|l|}{ Manage supplies } \\
\hline Adaptation to technological innovations & & & & & \\
\hline
\end{tabular}

19. Indicate the level of complexity of the political-contextual environment in the accounting profession; consider " 1 " the most complex and " 5 " the least complex. 


\begin{tabular}{|c|c|c|c|c|c|}
\hline \multirow{2}{*}{ Political-Contextual Environment } & \multicolumn{5}{|c|}{ Complexity } \\
\hline & 1 & 2 & 3 & 4 & 5 \\
\hline \multicolumn{6}{|l|}{ Adaptation to hierarchical structures } \\
\hline \multicolumn{6}{|c|}{ Management of sub levels in different structures hierarchies } \\
\hline \multicolumn{6}{|l|}{ Interdependence between hierarchical levels } \\
\hline \multicolumn{6}{|l|}{ Distribution of tasks } \\
\hline \multicolumn{6}{|l|}{ Linking projects with the political environment } \\
\hline \multicolumn{6}{|l|}{ Linking projects with the business environment } \\
\hline \multicolumn{6}{|l|}{ Linking projects with the social environment } \\
\hline Relationship with other organizations & & & & & \\
\hline
\end{tabular}

20. Indicate the level of complexity of the ethical-social environment in the accounting profession; consider " 1 " the most complex and " 5 " the least complex.

\begin{tabular}{|c|c|c|c|c|c|}
\hline \multirow{2}{*}{ Ethical-Social Environment } & \multicolumn{5}{|c|}{ Complexity } \\
\hline & 1 & 2 & 3 & 4 & 5 \\
\hline \multicolumn{6}{|l|}{ Good relations between the human resources involved in a project } \\
\hline \multicolumn{6}{|l|}{ Respect for the social and cultural values of each person } \\
\hline \multicolumn{6}{|l|}{ Teamwork } \\
\hline \multicolumn{6}{|l|}{ Cooperative learning from the experiences and knowledge of others } \\
\hline Appropriate behaviour according to the context & & & & & \\
\hline
\end{tabular}

21. Indicate the level of importance of the methods that you consider the most efficient to reduce the complexity of an accountant's jobs; consider " 1 " the most important and "5" the least important.

\begin{tabular}{|c|c|c|c|c|c|}
\hline \multirow{2}{*}{ Method } & \multicolumn{5}{|c|}{ Importance } \\
\hline & 1 & 2 & 3 & 4 & 5 \\
\hline \multicolumn{6}{|l|}{ Development of tasks in companies with employees } \\
\hline \multicolumn{6}{|l|}{ Train employees in a group } \\
\hline \multicolumn{6}{|l|}{ Develop incentives for teams } \\
\hline Applying constant evaluations to the work developed & & & & & \\
\hline
\end{tabular}

22. Indicate the level of importance of the following educational activities for the development of competences in accounting students; consider " 1 " very important and " 5 " not important at all.

Educational Activities

University students taught Accounting subjects in colleges

Accounting and tax advisory office, from students for the community and small entrepreneurs.

Realization of an accounting process in spreadsheets (Excel).

Realization of financial statements in real companies. 
Educational Activities

\begin{tabular}{l}
\hline Imparting of reinforcement courses. \\
\hline Learning through videoconferencing. \\
\hline Work in groups in the classroom. \\
\hline Accounting commercial software in the classroom. \\
\hline Professional internships in real companies. \\
\hline Advice about entrepreneurship, accounting, taxation and basic \\
finance in rural communities. \\
\hline Management consulting in real companies. \\
\hline Individual or group tutorials. \\
\hline Business simulation in the classroom \\
\hline Study of real cases of fraud in the classroom. \\
\hline Transmission of experiences with alumnus \\
\hline Learning through research and academic articles \\
\hline Project-Based Learning (PBL) \\
\hline
\end{tabular}

23. Indicate the importance level of the following competences of an accountant; consider " 1 " very important and " 5 " not important at all.

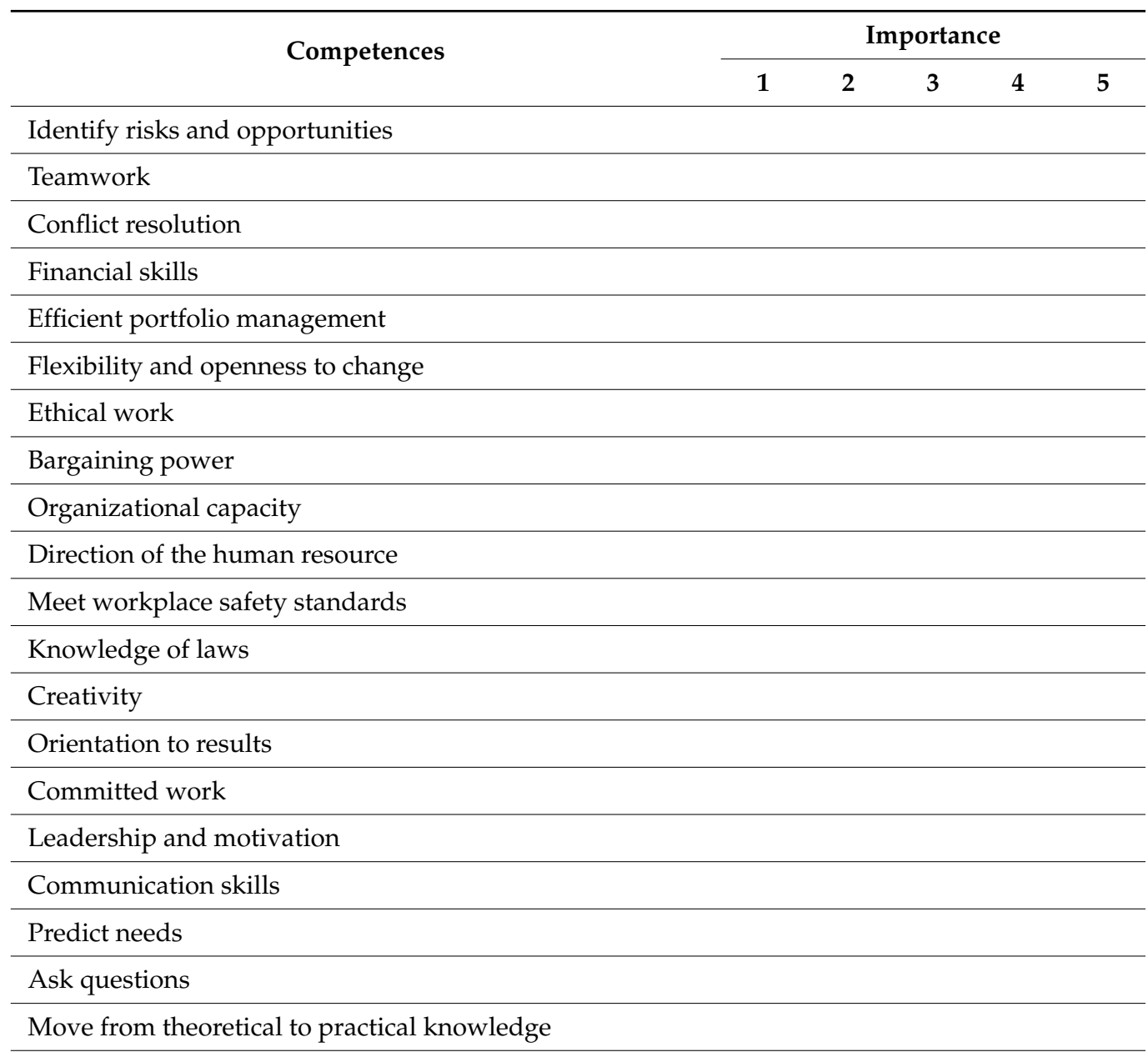




\begin{tabular}{|c|c|c|c|c|c|}
\hline \multirow{2}{*}{ Competences } & \multicolumn{5}{|c|}{ Importance } \\
\hline & 1 & 2 & 3 & 4 & 5 \\
\hline \multicolumn{6}{|l|}{ Integrate processes } \\
\hline \multicolumn{6}{|l|}{ Capacity for debate } \\
\hline \multicolumn{6}{|l|}{ Generate objectives for projects } \\
\hline \multicolumn{6}{|l|}{ Structure projects } \\
\hline \multicolumn{6}{|l|}{ Fulfill times and phases when developing projects } \\
\hline \multicolumn{6}{|l|}{ Close contracts } \\
\hline \multicolumn{6}{|l|}{ Prepare reports } \\
\hline \multicolumn{6}{|l|}{ Start up projects } \\
\hline \multicolumn{6}{|l|}{ Relaxation capacity and work under pressure } \\
\hline \multicolumn{6}{|l|}{ Self-control } \\
\hline \multicolumn{6}{|l|}{ Reliability } \\
\hline \multicolumn{6}{|l|}{ Appreciation of values } \\
\hline \multicolumn{6}{|l|}{ Project orientation } \\
\hline Programs orientation & & & & & \\
\hline
\end{tabular}

24. Do you consider that the participation of students in educational projects increases their competences and reduces the complexities in future jobs?

- Yes

- Not

Why?

\section{Appendix B. Questionnaire for Research on the Development of Competencies in} Accounting Students

Presentation: This instrument is applied to continue with the research about the development of competences in college students and to collect information for the design of a model of Educational Projects that allows to improve skills in accounting and audit students.

Please answer the following questions. Thank you.

1. Gender

- Female

- Male

- Other

2. First and last name

3. Email

4. Country

5. What is the name of the University in which you work?

6. For the development of an educational method that allows to generate more competences in the university students of the careers of accounting, what do you think are the most appropriate methods in each of the following groups? Rate its order of importance as indicated in each one.

The educational methods are arranged according to the factor analysis applied to the answers of the first phase of this investigation.

Please Order the following items at your discretion from 1 to 10: considering 1 the most important, and 10 the least important. 


\begin{tabular}{l}
\hline Management consulting in real companies. \\
\hline Professional internships in real companies. \\
\hline Realization of financial statements in real companies. \\
\hline $\begin{array}{l}\text { Accounting and tax advisory office, from students for the community and small } \\
\text { entrepreneurs. }\end{array}$ \\
\hline Study of real cases of fraud in the classroom \\
\hline $\begin{array}{l}\text { Advice about entrepreneurship, accounting, taxation and basic finance in rural } \\
\text { communities. }\end{array}$ \\
\hline Accounting commercial software in the classroom \\
\hline Transmission of experiences with alumnus \\
\hline Project-Based Learning (PBL) \\
\hline Realization of an accounting process in spreadsheets (Excel). \\
\hline
\end{tabular}

Please Order the following items at your discretion from 1 to 6 , considering 1 the most important, and 6 the least important.

\begin{tabular}{l}
\hline Work in groups in the classroom. \\
\hline Learning through videoconferencing \\
\hline Individual or group tutorials. \\
\hline Business simulation in the classroom \\
\hline Imparting of reinforcement courses. \\
\hline Learning through research and academic articles \\
\hline
\end{tabular}

7. The skills of an accountant according to the applied factor analysis are divided into four groups. Rate their order of importance in each group as indicated below:

Please Order the following items at your discretion from 1 to 18 , considering 1 the most important, and 18 the least important.

\begin{tabular}{l}
\hline Appreciation of values \\
\hline Ethical work \\
\hline Financial skills \\
\hline Reliability \\
\hline Bargaining power \\
\hline Communication skills \\
\hline Move from theoretical to practical knowledge \\
\hline Identify risks and opportunities \\
\hline Asking questions \\
\hline Conflict resolution \\
\hline Self-control \\
\hline Teamwork \\
\hline Efficient portfolio management \\
\hline Orientation to results
\end{tabular}




\begin{tabular}{l}
\hline Integrate processes \\
\hline Knowledge of laws \\
\hline Flexibility and openness to change \\
\hline Prepare reports \\
\hline
\end{tabular}

Please Order the following items at your discretion from 1 to 7 , considering 1 the most important, and 7 the least important.

\begin{tabular}{l}
\hline Start up projects \\
\hline Human Resources management \\
\hline Structure projects \\
\hline Programs orientation \\
\hline Project orientation \\
\hline Generate objectives for projects \\
\hline Organizational capacity \\
\hline
\end{tabular}

Please Order the following items at your discretion from 1 to 5 , considering 1 the most important, and 5 the least important.

\begin{tabular}{l}
\hline Creativity \\
\hline Leadership and motivation \\
\hline Capacity for debate \\
\hline Committed work \\
\hline Close contracts \\
\hline
\end{tabular}

Please Order the following items at your discretion from 1 to 4 , considering 1 the most important, and 4 the least important.

\begin{tabular}{l}
\hline Meet workplace safety standards \\
\hline Relaxation capacity and work under pressure \\
\hline Fulfill times and phases when developing projects \\
\hline Predict needs \\
\hline
\end{tabular}

8. In which college level do you consider each of the following educational methods should be applied?

\begin{tabular}{|c|c|c|c|c|}
\hline Educational Method & $\begin{array}{l}\text { First } \\
\text { Year }\end{array}$ & $\begin{array}{l}\text { Second } \\
\text { Year }\end{array}$ & $\begin{array}{l}\text { Third } \\
\text { Year }\end{array}$ & $\begin{array}{l}\text { Fourth } \\
\text { Year }\end{array}$ \\
\hline \multicolumn{5}{|l|}{ Management consulting in real companies. } \\
\hline \multicolumn{5}{|l|}{ Professional internships in real companies. } \\
\hline \multicolumn{5}{|l|}{ Realization of financial statements in real companies. } \\
\hline \multicolumn{5}{|l|}{$\begin{array}{l}\text { Accounting and tax advisory office, from students for the } \\
\text { community and small entrepreneurs. }\end{array}$} \\
\hline \multicolumn{5}{|l|}{ Study of real cases of fraud in class } \\
\hline $\begin{array}{l}\text { Advice about entrepreneurship, accounting, taxation and } \\
\text { basic finance in rural communities. }\end{array}$ & & & & \\
\hline
\end{tabular}




\begin{tabular}{lll}
\hline \multicolumn{1}{c}{ Educational Method } & $\begin{array}{l}\text { First } \\
\text { Year }\end{array}$ & $\begin{array}{l}\text { Second } \\
\text { Year }\end{array}$ \\
\hline Accounting commercial software in class & $\begin{array}{c}\text { Fourth } \\
\text { Year }\end{array}$ \\
\hline Transmission of experiences with alumnus & \\
\hline Project-Based Learning (PBL) & \\
\hline Realization of an accounting process in spreadsheets (Excel). \\
\hline Work in groups in the classroom. \\
\hline Learning through videoconferencing \\
\hline Individual or group tutorials. \\
\hline Business simulation in class \\
\hline Reinforcement courses. \\
\hline Learning through research and academic articles \\
\hline
\end{tabular}

9. From the following list of skills, which ones do you think are most related to each educational method proposed? Place the numeral of the method next to each skill.

\begin{tabular}{cl}
\hline Numeral & \multicolumn{1}{c}{ Educational Method } \\
\hline 1 & Management consulting in real companies. \\
\hline 2 & Professional internships in real companies. \\
\hline 3 & Realization of financial statements in real companies. \\
\hline 5 & $\begin{array}{l}\text { Accounting and tax advisory office, from students for the community and small } \\
\text { entrepreneurs. }\end{array}$ \\
\hline 6 & Study of real cases of fraud in class \\
\hline 7 & Entrepreneurship, accounting, taxation and basic finance in rural communities \\
\hline 8 & Accounting commercial software in class \\
\hline 9 & Project-Based Learning (PBL) \\
\hline 10 & Realization of an accounting process in spreadsheets (Excel). \\
\hline 11 & Work in groups in class \\
\hline 12 & Learning through videoconferencing \\
\hline 13 & Individual or group tutorials. \\
\hline 14 & Business simulation in class \\
\hline 15 & Imparting of reinforcement courses. \\
\hline 16 & Learning through research and academic articles \\
\hline
\end{tabular}

Relate each competition with a method.

\begin{tabular}{ll}
\hline \multicolumn{1}{c}{ Competences } & Numeral of the Educational Method \\
\hline Appreciation of values & \\
\hline Ethical work & \\
\hline Financial skills \\
\hline Reliability \\
\hline Bargaining power
\end{tabular}




\begin{tabular}{|c|c|}
\hline Competences & Numeral of the Educational Method \\
\hline \multicolumn{2}{|l|}{ Communication skills } \\
\hline \multicolumn{2}{|l|}{ Move from theoretical to practical knowledge } \\
\hline \multicolumn{2}{|l|}{ Identify risks and opportunities } \\
\hline \multicolumn{2}{|l|}{ Asking questions } \\
\hline \multicolumn{2}{|l|}{ Conflict resolution } \\
\hline \multicolumn{2}{|l|}{ Self-control } \\
\hline \multicolumn{2}{|l|}{ Teamwork } \\
\hline \multicolumn{2}{|l|}{ Efficient portfolio management } \\
\hline \multicolumn{2}{|l|}{ Orientation to results } \\
\hline \multicolumn{2}{|l|}{ Processes integration } \\
\hline \multicolumn{2}{|l|}{ Knowledge of laws } \\
\hline \multicolumn{2}{|l|}{ Flexibility and openness to change } \\
\hline \multicolumn{2}{|l|}{ Reports preparation } \\
\hline \multicolumn{2}{|l|}{ Start up projects } \\
\hline \multicolumn{2}{|l|}{ Human Resources management } \\
\hline \multicolumn{2}{|l|}{ Structure projects } \\
\hline \multicolumn{2}{|l|}{ Programs orientation } \\
\hline \multicolumn{2}{|l|}{ Project orientation } \\
\hline \multicolumn{2}{|l|}{ Generate objectives for projects } \\
\hline \multicolumn{2}{|l|}{ Organizational capacity } \\
\hline \multicolumn{2}{|l|}{ Creativity } \\
\hline \multicolumn{2}{|l|}{ Leadership and motivation } \\
\hline \multicolumn{2}{|l|}{ Capacity for debate } \\
\hline \multicolumn{2}{|l|}{ Committed work } \\
\hline \multicolumn{2}{|l|}{ Close contracts } \\
\hline \multicolumn{2}{|l|}{ Meet workplace safety standards } \\
\hline \multicolumn{2}{|l|}{ Relaxation capacity and work under pressure } \\
\hline \multicolumn{2}{|l|}{$\begin{array}{l}\text { Fulfill times and phases when developing } \\
\text { projects }\end{array}$} \\
\hline Predict needs & \\
\hline
\end{tabular}

Appendix C. Questionnaire to Determine the Viability of the Hybrid Model of Methods in Accounting Careers

Please answer the following questions:

How many years of professional experience do you have?

1. Age

2. Indicate your highest degree you have completed

- Bachelor's degree

- Master's Degree

- Advanced Graduate work or Ph.D.

3. Is the model presented applicable to Accounting Careers?

4. Why? 
5. To what extent the Hybrid Model of Methods would increase the following competencies, unlike the traditional pedagogical model applied in accounting careers? Rate from 1 to 5 considering 5 significantly and 1 nothing.

\begin{tabular}{|c|c|c|c|c|}
\hline Competencies & 1 & 2 & 3 & 4 \\
\hline \multicolumn{5}{|l|}{ Identify risks and opportunities } \\
\hline \multicolumn{5}{|l|}{ Teamwork } \\
\hline \multicolumn{5}{|l|}{ Conflict resolution } \\
\hline \multicolumn{5}{|l|}{ Financial skills } \\
\hline \multicolumn{5}{|l|}{ Efficient portfolio management } \\
\hline \multicolumn{5}{|l|}{ Flexibility and openness to change } \\
\hline \multicolumn{5}{|l|}{ Ethical work } \\
\hline \multicolumn{5}{|l|}{ Bargaining power } \\
\hline \multicolumn{5}{|l|}{ Organizational capacity } \\
\hline \multicolumn{5}{|l|}{ Direction of the human resource } \\
\hline \multicolumn{5}{|l|}{ Meet workplace safety standards } \\
\hline \multicolumn{5}{|l|}{ Knowledge of laws } \\
\hline \multicolumn{5}{|l|}{ Creativity } \\
\hline \multicolumn{5}{|l|}{ Orientation to results } \\
\hline \multicolumn{5}{|l|}{ Committed work } \\
\hline \multicolumn{5}{|l|}{ Leadership and motivation } \\
\hline \multicolumn{5}{|l|}{ Communication skills } \\
\hline \multicolumn{5}{|l|}{ Predict needs } \\
\hline \multicolumn{5}{|l|}{ Ask questions } \\
\hline \multicolumn{5}{|l|}{ Move from theoretical to practical knowledge } \\
\hline \multicolumn{5}{|l|}{ Integrate processes } \\
\hline \multicolumn{5}{|l|}{ Capacity for debate } \\
\hline \multicolumn{5}{|l|}{ Generate objectives for projects } \\
\hline \multicolumn{5}{|l|}{ Structure projects } \\
\hline \multicolumn{5}{|l|}{ Fulfill times and phases when developing projects } \\
\hline \multicolumn{5}{|l|}{ Close contracts } \\
\hline \multicolumn{5}{|l|}{ Prepare reports } \\
\hline \multicolumn{5}{|l|}{ Start up projects } \\
\hline \multicolumn{5}{|l|}{ Relaxation capacity and work under pressure } \\
\hline Self-control & & & & \\
\hline Reliability & & & & \\
\hline Appreciation of values & & & & \\
\hline Project orientation & & & & \\
\hline Programs orientation & & & & \\
\hline
\end{tabular}

6. Indicate to what extent the model would help improve the skills to develop the following activities in the accounting profession. Rate from 1 to 5 considering 5 significantly and 1 nothing. 


\begin{tabular}{|c|c|c|c|c|c|}
\hline Activities & 1 & 2 & 3 & 4 & 5 \\
\hline \multicolumn{6}{|l|}{ Develop objectives } \\
\hline \multicolumn{6}{|l|}{ Identify needs for change when there is uncertainty } \\
\hline \multicolumn{6}{|l|}{ Manage times to achieve goals } \\
\hline \multicolumn{6}{|l|}{ Develop tasks in different degrees of complexity } \\
\hline \multicolumn{6}{|l|}{ Application of different methods to develop the same task } \\
\hline \multicolumn{6}{|l|}{ Manage supplies } \\
\hline \multicolumn{6}{|l|}{ Adaptation to technological innovations } \\
\hline \multicolumn{6}{|l|}{ Adaptation to hierarchical structures } \\
\hline \multicolumn{6}{|l|}{ Management of sub levels in different structures hierarchies } \\
\hline \multicolumn{6}{|l|}{ Interdependence between hierarchical levels } \\
\hline \multicolumn{6}{|l|}{ Distribution of tasks } \\
\hline \multicolumn{6}{|l|}{ Linking projects with the political environment } \\
\hline \multicolumn{6}{|l|}{ Linking projects with the business environment } \\
\hline \multicolumn{6}{|l|}{ Linking projects with the social environment } \\
\hline \multicolumn{6}{|l|}{ Relationship with other organizations } \\
\hline \multicolumn{6}{|l|}{$\begin{array}{l}\text { Good relations between the human resources involved in a } \\
\text { project }\end{array}$} \\
\hline \multicolumn{6}{|l|}{ Respect for the social and cultural values of each person } \\
\hline \multicolumn{6}{|l|}{ Teamwork } \\
\hline \multicolumn{6}{|l|}{$\begin{array}{l}\text { Cooperative learning from the experiences and knowledge } \\
\text { of others }\end{array}$} \\
\hline \multicolumn{6}{|l|}{ Appropriate behaviour according to the context } \\
\hline \multicolumn{6}{|l|}{ Well defined personality } \\
\hline \multicolumn{6}{|l|}{ Development of tasks in companies with employees } \\
\hline \multicolumn{6}{|l|}{ Train employees in a group } \\
\hline \multicolumn{6}{|l|}{ Develop incentives for teams } \\
\hline Applying constant evaluations to the work developed & & & & & \\
\hline
\end{tabular}

\section{Appendix D. Questionnaire for the Research and Development of an Educational Model That Generates Competences in the Students of the Accounting and Audit Career}

Directed to the Students of the Accounting and Audit career of Universidad Politécnica Salesiana.

Presentation: This instrument is applied to determine the perception and recommendations of students of Accounting and Auditing career about the educational methods used in the teaching-learning process and collect information for the design of a model of Educational Projects that allows them improving their professional competencies.

1. Gender

- Female

- Male

- Other

2. Age

3. What academic level are you in?

4. What should universities do?

- Apply more practical methods 
- $\quad$ Stay as they are

5. Rate how you consider the current education system of accounting careers in your country, considering 1 very good and 5 very bad.

$\begin{array}{lllll}1 & 2 & 3 & 4 & 5\end{array}$

6. Indicate in which of the following methods you have participated.

\begin{tabular}{l}
\hline Management consulting in real companies. \\
\hline Professional internships in real companies. \\
\hline Realization of financial statements in real companies. \\
\hline $\begin{array}{l}\text { Accounting and tax advisory office, from students for the community and small } \\
\text { entrepreneurs. }\end{array}$ \\
\hline Study of real cases of fraud in the classroom \\
\hline $\begin{array}{l}\text { Advice about entrepreneurship, accounting, taxation and basic finance in rural } \\
\text { communities. }\end{array}$ \\
\hline Accounting commercial software in the classroom \\
\hline Transmission of experiences with alumnus \\
\hline Project-Based Learning (PBL) \\
\hline Realization of an accounting process in spreadsheets (Excel). \\
\hline Work in groups in the classroom. \\
\hline Learning through videoconferencing \\
\hline Individual or group tutorials. \\
\hline Business simulation in the classroom \\
\hline Imparting of reinforcement courses. \\
\hline Learning through research and academic articles \\
\hline
\end{tabular}

7. Rate each method from 1 to 5 , according to how you consider that these will contribute to your professional development, considering 5 the best score and 1 the worst score.

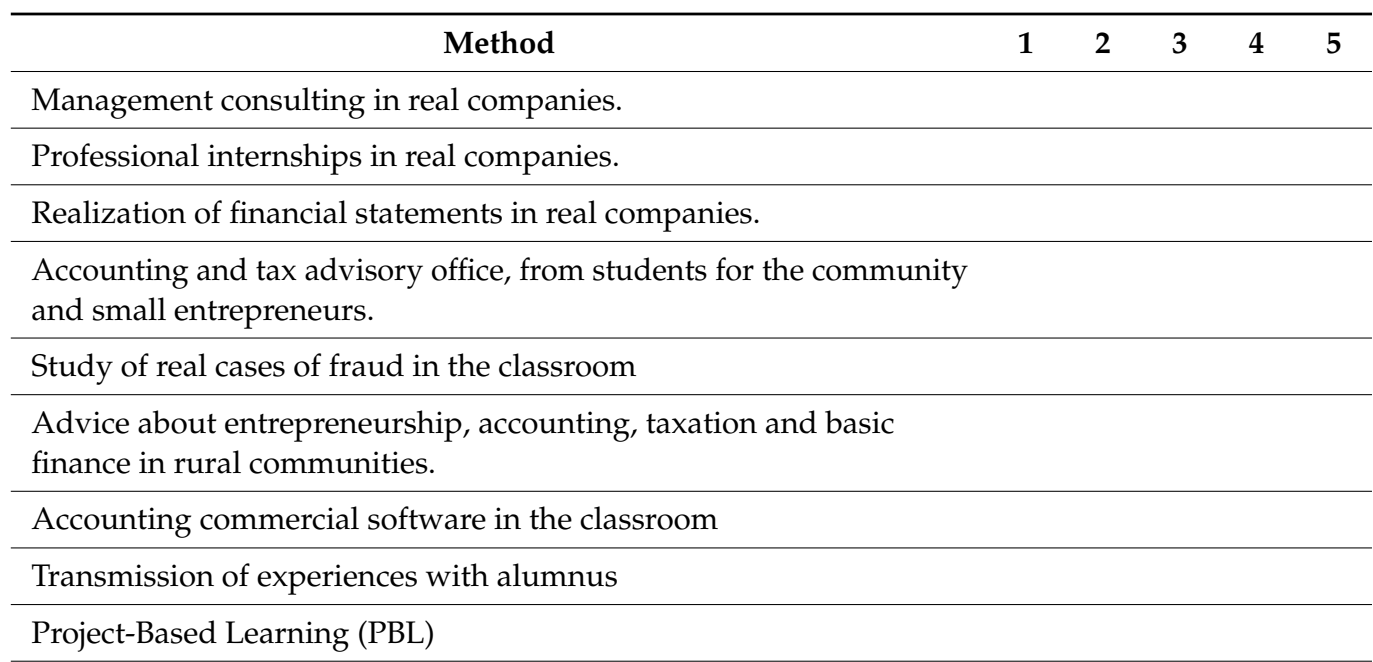




\begin{tabular}{|c|c|c|c|c|c|}
\hline Method & 1 & 2 & 3 & 4 & 5 \\
\hline \multicolumn{6}{|c|}{ Realization of an accounting process in spreadsheets (Excel). } \\
\hline \multicolumn{6}{|l|}{ Work in groups in the classroom. } \\
\hline \multicolumn{6}{|l|}{ Learning through videoconferencing } \\
\hline \multicolumn{6}{|l|}{ Individual or group tutorials. } \\
\hline \multicolumn{6}{|l|}{ Business simulation in the classroom } \\
\hline \multicolumn{6}{|l|}{ Imparting of reinforcement courses. } \\
\hline Learning through research and academic articles & & & & & \\
\hline
\end{tabular}

8. Indicate the level (academic cycle) in which each method should be applied.

\begin{tabular}{|c|c|c|c|c|c|c|c|c|c|}
\hline \multirow{2}{*}{ Method } & \multicolumn{9}{|c|}{ Level } \\
\hline & 1 & 2 & 3 & 4 & 5 & 6 & 7 & 8 & 9 \\
\hline \multicolumn{10}{|l|}{ Management consulting in real companies. } \\
\hline \multicolumn{10}{|l|}{ Professional internships in real companies. } \\
\hline \multicolumn{10}{|l|}{ Realization of financial statements in real companies. } \\
\hline \multicolumn{10}{|l|}{$\begin{array}{l}\text { Accounting and tax advisory office, from students for } \\
\text { the community and small entrepreneurs. }\end{array}$} \\
\hline \multicolumn{10}{|l|}{ Study of real cases of fraud in the classroom } \\
\hline \multicolumn{10}{|l|}{$\begin{array}{l}\text { Advice about entrepreneurship, accounting, taxation } \\
\text { and basic finance in rural communities. }\end{array}$} \\
\hline \multicolumn{10}{|l|}{ Accounting commercial software in the classroom } \\
\hline \multicolumn{10}{|l|}{ Transmission of experiences with alumnus } \\
\hline \multicolumn{10}{|l|}{ Project-Based Learning (PBL) } \\
\hline \multicolumn{10}{|l|}{$\begin{array}{l}\text { Realization of an accounting process in spreadsheets } \\
\text { (Excel). }\end{array}$} \\
\hline \multicolumn{10}{|l|}{ Work in groups in the classroom. } \\
\hline \multicolumn{10}{|l|}{ Learning through videoconferencing } \\
\hline \multicolumn{10}{|l|}{ Individual or group tutorials. } \\
\hline \multicolumn{10}{|l|}{ Business simulation in the classroom } \\
\hline \multicolumn{10}{|l|}{ Imparting of reinforcement courses. } \\
\hline Learning through research and academic articles & & & & & & & & & \\
\hline
\end{tabular}

\section{References}

1. Carrera, P. Diseño del Sistema Académico Por Competencias de la Escuela de Turismo y Hospitalidad de la Pontificia Universidad Católica del Ecuador. Gestión Turística 2010, 13, 113-127. [CrossRef]

2. Beard, D.F. The status of internships/cooperative education experiences in accounting education. J. Account. Educ. 1998, 16, 507-516. [CrossRef]

3. Dyball, M.C.; Reid, A.; Ross, P.; Schoch, H. Compulsory group work-Accounting students' conceptions and suggestions. Asian Rev. Account. 2010, 18, 92-105. [CrossRef]

4. De la Rosa Ruiz, D.; Giménez Armentia, P.; De la Calle Maldonado, C. Educación para el desarrollo sostenible: El papel de la universidad en la Agenda 2030. Revista Prisma Social 2019, 179-202. Available online: https:/ / revistaprismasocial.es/article/ view / 2709 (accessed on 12 March 2021).

5. Moşteanu, N.R.; Faccia, A. Digital Systems and New Challenges of Financial Management-FinTech, XBRL, Blockchain and Cryptocurrencies. Qual. Access Success J. 2020, 21, 159-166.

6. Peters, E.; Kliestik, T.; Musa, H.; Durana, P. Product decision-making information systems, real-time big data analytics, and deep learning-enabled smart process planning in sustainable industry 4.0. J. Self-Gov. Manag. Econ. 2020, 8, 16-22. 
7. Duft, G.; Durana, P. Artificial Intelligence-based Decision-Making Algorithms, Automated Production Systems, and Big Datadriven Innovation in Sustainable Industry 4.0. Econ. Manag. Financ. Mark. 2020, 15, 9-18.

8. Irving, J.H. Integrating Research into an Undergraduate Accounting Course. Issues Account. Educ. 2011, 26, 287-303. [CrossRef]

9. James, K. A Critical Theory and Postmodernist approach to the teaching of accounting theory. Crit. Perspect. Account. 2008, 19, 643-676. [CrossRef]

10. Lam, J.Y.; Chan, R.K.; Yan, K.Y. A report on the online learning experience of students in accounting course. Int. J. Serv. Stand. 2015, 10, 192. [CrossRef]

11. Mantilla, L.M.; Carvajal, E.T. Las Competencias del contador-auditor que labora en el sector público. Augusto Guzzo Rev. Acadêmica 2017, 1, 9-20. [CrossRef]

12. Bhasin, M.L. Corporate governance and forensic accountant: An exploratory study. J. Account. Bus. Manag. JABM 2013, 20, 55-75.

13. Markides, C. In Search of Ambidextrous Professors. Acad. Manag. J. 2007, 50, 762-768. [CrossRef]

14. Moncada, L. Determinantes inmediatos del rendimiento académico en los nuevos estudiantes matriculados en el sistema de educación superior a distancia del Ecuador: Caso Universidad Técnica Particular de Loja, RIED. Rev. Iberoam. Educ. Distancia 2011, 14, 77-95. [CrossRef]

15. Morales, P. La Evaluación Académica: Conceptos y Planteamientos Básicos; Universidad de Deusto: Bizkaia, Spain, 2009; Volume 2, pp. $29-45$.

16. Mungal, A.; Cloete, M. Preparing underprepared students for higher education and beyond: The development and implementation of an integrated project. Account. Educ. 2016, 25, 203-222. [CrossRef]

17. O'Donnell, A.M.; King, A. Cognitive Perspectives on Peer Learning, 1st ed.; Routledge: Oxford, UK, 2014. [CrossRef]

18. King, S.; Vardon, M.; Grantham, H.S.; Eigenraam, M.; Ferrier, S.; Juhn, D.; Turner, K. Linking biodiversity into national economic accounting. Environ. Sci. Policy 2021, 116, 20-29. [CrossRef]

19. Ortiz, M.J.D.; Hernández, M.M.; Reyes, A.A. October 2012, Generic and professional skills: An analytical approach to the degree in accounting. In Proceedings of the XVII International Congress of Accounting Administration and Information Technology, Troyes, France, 9-11 June 2007.

20. Fransen, L. The embeddedness of responsible business practice: Exploring the interaction between national-institutional environments and corporate social responsibility. J. Bus. Ethics 2013, 115, 213-227. [CrossRef]

21. Parginos, A. Corporate Social Responsibility and Socio-Environmental Reporting Practices: Evidence from an Exploratory Study in the Greek Context. Ph.D. Thesis, University of Essex, Colchester, UK, 2021.

22. Palazuelos, E.; San Martín, P.; Montoya del Corte, J.; Fernández-Laviada, A. Utilidad percibida del Aprendizaje Orientado a Proyectos para la formación de competencias. Appl. Asign. Audit. Cuentas Rev. Contab. 2018, 21, 150-161. [CrossRef]

23. Palma, M.; de los Ríos, I.; Miñán, E.; Luy, G. Hacia un Nuevo Modelo desde las Competencias: La Ingeniería Industrial en el Perú, Tenth LACCEI Latin American and Caribbean Conference, Recuperado de. 2012. Available online: https://www.usfx.bo/nueva/ vicerrectorado/citas/TECNOLOGICAS_20/Ingenieria_Industrial/MP\%20Lama.pdf (accessed on 6 July 2021).

24. Boulianne, E. Impact of accounting software utilization on students' knowledge acquisition. J. Account. Organ. Chang. 2014, 10, 22-48. [CrossRef]

25. Islam, M.A. Future of accounting profession: Three major changes and implications for teaching and research. In Business Reporting; International Federation of Accountants (IFAC): New York, NY, USA, 2017. Available online: https://www.ifac.org/globalknowledge-gateway/business-reporting/discussion/future-accounting-profession-three-major (accessed on 10 April 2021).

26. Pee, L.G.; Kankanhalli, A. A Model of Organisational Knowledge Management Maturity Based on People, Process, and Technology. J. Inf. Knowl. Manag. 2009, 8, 79-99. [CrossRef]

27. Florit, D.P.; Montaño, J.L.A.; Anes, J.A.D. Distance learning and academic performance in accounting: A comparative study of the effect of the use of videoconferencing. Rev. Contab. 2012, 15, 195-209. [CrossRef]

28. Rodríguez, M.C.L.; Rico, Y.M.S. Competencias del contador público: Una mirada desde la Educación Superior y los requerimientos de las PyME comerciales en Bogotá. Teuken Bidikay 2017, 8, 149-176. Available online: http:/ / revistas.elpoli.edu.co/index.php/ teu/article/view/1206 (accessed on 5 March 2021).

29. Smith, K.A.; Sheppard, S.D.; Johnson, D.W.; Johnson, R.T. Pedagogies of Engagement: Classroom-Based Practices. J. Eng. Educ. 2005, 94, 87-101. Available online: https:/ / onlinelibrary.wiley.com/doi/abs/10.1002/j.2168-9830.2005.tb00831.x (accessed on 6 July 2021). [CrossRef]

30. Bui, B.; Porter, B. The Expectation-Performance Gap in Accounting Education: An Exploratory Study. Account. Educ. 2010, 19, 23-50. [CrossRef]

31. Pizzi, S.; Rosati, F.; Venturelli, A. The determinants of business contribution to the 2030 Agenda: Introducing the SDG Reporting Score. Bus. Strategy Environ. 2021, 30, 404-421. [CrossRef]

32. Schmidt, H.G.; Rotgans, J.; Yew, E.H.J. The process of problem-based learning: What works and why. Med. Educ. 2011, 45, 792-806. [CrossRef] [PubMed]

33. Ahn, B.; Nelson, M. Assessment of the effects of using the cooperative learning pedagogy in a hybrid mechanics of materials course. Int. J. Mech. Eng. Educ. 2018, 47, 210-226. [CrossRef]

34. Eberlein, T.; Kampmeier, J.; Minderhout, V.; Moog, R.S.; Platt, T.; Varma-Nelson, P.; White, H.B. Pedagogies of engagement in science. A comparison of PBL, POGIL, and PLTL. Biochem. Mol. Biol. Educ. 2008, 36, 262-273. [CrossRef] 
35. Thistlethwaite, J.E.; Davies, D.; Ekeocha, S.; Kidd, J.M.; MacDougall, C.; Matthews, P.; Purkis, J.; Clay, D. The effectiveness of case-based learning in health professional education. A BEME systematic review: BEME Guide No. 23. Med. Teach. 2012, 34, e421-e444. [CrossRef]

36. de los Ríos, I.; Cazorla, A.; Díaz-Puente, J.M.; Yagüe, J.L. Project-based learning in engineering higher education: Two decades of teaching competences in real environments. Procedia Soc. Behav. Sci. 2010, 2, 1368-1378. [CrossRef]

37. Markham, T. Project Based Learning a Bridge Just Far Enough. Teach. Libr. 2011, 39, 38-42. Available online: https://search. proquest.com/openview / c1fb978702898324f288f75dba836879/1?pq-origsite=gscholar\&cbl=38018 (accessed on 5 July 2021).

38. Tobón, S. La Formación Basada en Competencias en la Educación Superior: El Enfoque Complejo. Universidad Autónoma de Guadalajara Curso Iglu. 2008. Available online: http://cmapspublic3.ihmc.us/rid=1LVT9TXFX-1VKC0TM-16YT/Formaci\%C3 \%B3n\%20basada\%20en\%20competencias\%20(Sergio\%20Tob\%C3\%B3n).pdf (accessed on 15 March 2021).

39. Huber, M.M.; Mafi, S.L. Education par excellence: Developing personal competencies and character through philanthropy-based education. J. Account. Educ. 2013, 31, 310-332. [CrossRef]

40. De los Ríos-Carmenado, I.; Sastre-Merino, S.; Lantada, A.D.; García-Martín, J.; Nole, P.; Pérez-Martínez, J.E. Building World Class Universities through Innovative Teaching Governance. Stud. Educ. Eval. 2021, 70, 101031. Available online: https: //www.sciencedirect.com/science/article/abs/pii/S0191491X21000572 (accessed on 1 August 2021). [CrossRef]

41. Willis, V.F. A model for teaching technology: Using Excel in an accounting information systems course. J. Account. Educ. 2016, 36, 87-99. [CrossRef]

42. Howieson, B.; Hancock, P.; Segal, N.; Kavanagh, M.; Tempone, I.; Kent, J. Who should teach what? Australian perceptions of the roles of universities and practice in the education of professional accountants. J. Account. Educ. 2014, 32, 259-275. [CrossRef]

43. Grimm, S.D.; Blazovich, J.L. Developing student competencies: An integrated approach to a financial statement analysis project. J. Account. Educ. 2016, 35, 69-101. [CrossRef]

44. de los Ríos, I.; Rodriguez, F.; Pérez, C. Promoting Professional Project Management Skills in Engineering Higher Education: Project-Based Learning. Int. J. Eng. Educ. 2015, 32, 184-198.

45. Muñoz, C.; Carlos Martínez, C.; Xavier, J.; Villarreal, J.L. Estándares Internacionales de Educación (IES) en Contabilidad y Aseguramiento: Nuevos Retos de la Profesión Contable. Tendencias 2014, 15, 118-135. [CrossRef]

46. Cazorla, A.; de los Ríos, I.; Salvo, M. Working with People (WWP) in Rural Development Projects: A Proposal from Social Learning. Cuad. Desarro. Rural. 2013, 10, 131-157. Available online: http:/ /www.scielo.org.co/scielo.php?pid=S0122-1450201300 0100007\&script=sci_abstract\&tlng=en (accessed on 23 June 2021).

47. Skulmoski, G.; Hartman, F.T.; Krahn, J. The Delphi Method for Graduate Research. J. Inf. Technol. Educ. Res. 2007, 6, 1-21. Available online: https://www.learntechlib.org/p/111405/ (accessed on 1 July 2021). [CrossRef]

48. Mataix, C.; Romero, S.; Mazorra, J.; Moreno, J.; Ramil, X.; Stott, L.; Carrasco, J.; Lumbreras, J. Working for Sustainability Transformation in an Academic Environment: The Case of itdUPM. In Handbook of Theory and Practice of Sustainable Development in Higher Education; Leal Filho, W., Mifsud, M., Shiel, C., Pretorius, R., Eds.; World Sustainability Series; Springer: Cham, Switzerland, 2017. [CrossRef]

49. Faura-Martínez, Ú.; Lafuente-Lechuga, M.; García-Luque, O. Social and Territorial Cohesion in Spain: Relevance of the Socioeconomic Context. Soc. Indic. Res. 2020, 150, 501-547. [CrossRef]

50. de los Ríos, I.; Sastre, S.; Fernández, C.; Núñez del Río, M.C.; Reyes, E.; García, N. Proposals for Improving Assessment Systems in Higher Education: An Approach from the Model «Working with People». J. Technol. Sci. Educ. 2016, 6, 104-120. Available online: https: / / eric.ed.gov / ?id=EJ1134815 (accessed on 15 July 2021). [CrossRef]

51. Universia Argentina. 5 Técnicas de Estudio Efectivas que Recomiendan Desde la Universidad de Harvard, Universia; Universia Argentina: Buenos Aires, Argentina, 2018.

52. de los Ríos, I.; Morales, J. Social Learning in Rural Development Projects. In En Planning Experiences in Latin America and Europe, 1st ed.; Colegio de Postgraduados: Montecillo, México, 2015; pp. 184-186. Available online: http:/ / www.upm.es/observatorio/ vi/index.jsp?pageac=actividad.jsp\&id_actividad=229633 (accessed on 15 July 2021).

53. Migliorelli, M. What Do We Mean by Sustainable Finance? Assessing Existing Frameworks and Policy Risks. Sustainability 2021, 13, 975. [CrossRef]

54. Ojeda Suárez, R.; Agüero Contreras, F.C. Globalización, Agenda 2030 e imperativo de la educación superior: Reflexiones. Conrado 2019, 15, 125-134, Epub 02 de junio de 2019. Recuperado de. Available online: http:/ / scielo.sld.cu/scielo.php?script=sci_arttext\& pid=S1990-86442019000200125\&lng=es\&tlng=es (accessed on 10 July 2021).

55. Allen, S.J. On the cutting edge or the chopping block? Fostering a digital mindset and tech literacy in business management education. J. Manag. Educ. 2020, 44, 362-393. [CrossRef]

56. Mulà, I.; Tilbury, D.; Ryan, A.; Mader, M.; Dlouhá, J.; Mader, C.; Benayas, J.; Dlouhý, J.; Alba, D. Catalysing change in higher education for sustainable development: A review of professional development initiatives for university educators. Int. J. Sustain. High. Educ. 2017, 18, 798-820. [CrossRef]

57. Barrón, A.; Navarrete, A.; Ferrer-Balas, D. Sostenibilización curricular en las universidades españolas. ¿ha llegado la hora de actuar? La Revista Eureka Sobre Enseñanza y Divulgación De Las Ciencias 2010, 7, 388-399. 